\title{
Association studies for asthma and atopic diseases: a comprehensive review of the literature Sabine Hoffjan ${ }^{1}$, Dan Nicolae ${ }^{2}$ and Carole Ober*1
}

\begin{abstract}
Address: ${ }^{1}$ Departments of Human Genetics, The University of Chicago, Chicago, IL 60637, USA and ${ }^{2}$ Departments of Statistics, The University of Chicago, Chicago, IL 60637, USA

Email: Sabine Hoffjan - reimsbach@ hotmail.com; Dan Nicolae - nicolae@galton.uchicago.edu; Carole Ober* - c-ober@genetics.uchicago.edu

* Corresponding author
\end{abstract}

Published: 04 December 2003

Respiratory Research 2003, 4:14

This article is available from: http://respiratory-research.com/content/4/1/14 media for any purpose, provided this notice is preserved along with the article's original URL.

Received: 07 August 2003

Accepted: 04 December 2003

\begin{abstract}
Hundreds of genetic association studies on asthma-related phenotypes have been conducted in different populations. To date, variants in 64 genes have been reported to be associated with asthma or related traits in at least one study. Of these, 33 associations were replicated in a second study, 9 associations were not replicated either in a second study or a second sample in the same study, and 22 associations were reported in just a single published study. These results suggest the potential for a great amount of heterogeneity underlying asthma. However, many of these studies are methodologically limited and their interpretation hampered by small sample sizes.
\end{abstract}

\section{Review}

Two general approaches have been widely used to study the genetics of asthma: genome-wide linkage studies followed by positional cloning and candidate gene association studies. The results of linkage studies for asthma have been described in detail elsewhere [1-3]; this review focuses on the published candidate gene association studies for asthma.

\section{Candidate gene approach: basic principles and potential problems}

"Candidate genes" are selected because their biological function suggests that they could play a role in the pathophysiology of asthma (such as genes encoding cytokines and their receptors, chemokines and their receptors, transcription factors, IgE receptor, etc.). Association studies between variation in these candidate genes and asthmarelated phenotypes are mostly conducted in unrelated case and unrelated control samples by comparing allele or genotype frequencies between samples. Association studies with candidate genes are appealing because they are hypothesis-driven and can identify genetic variation that has relatively modest effects on susceptibility [4]. Compared with linkage analysis, case-control studies are much simpler to perform and less costly because they do not require the collection of families. However, the interpretation of association studies is not always straightforward (for example, see ref. [5]). In particular, there are a large number of negative association studies with candidate genes that are never reported. Because the reported p-values are rarely adjusted for the total number of studies performed (both reported and unreported), the type I error rate in the reported studies is actually higher than the nominal level.

A statistically significant association between a variant in a candidate gene and a disease phenotype can have three possible explanations. (1) The marker allele truly affects gene function by altering the amino-acid sequence or by modifying splicing, transcriptional properties, or mRNA stability, and thereby directly affects disease risk. (2) The marker allele is in linkage disequilibrium (LD) with the 
true disease-causing variant. LD, or allelic association, is the nonrandom association of alleles at linked loci in populations, and will usually only be detected over small distances ( $\leq 60$ approximated $\mathrm{kb}$ ) [6,7], although LD over longer distances has been observed. Thus, the marker allele must be located in relatively close proximity to the disease-causing variant. (3) The association is a false-positive result (type I error). Using a p-value of 0.05 as the threshold for significance will result in a 5\% type I error rate. However, in most cases p-values are calculated using large sample approximations. As a result, the probability of type I errors for many of these approximations is higher than the nominal p-value when the sample size is small, as it is in most published studies. Further, false-positive results are more likely if multiple comparisons are made, either with multiple polymorphisms in the same gene, polymorphisms in multiple genes, or with multiple phenotypes. In these cases, the $5 \%$ false positive rate expected when the null hypothesis (of no association) is rejected at $\mathrm{p}<0.05$ no longer applies because there is a 5\% type I error rate expected with each independent comparison (for example, with polymorphisms in different genes). A common correction for multiple comparisons is to multiply the p-values by the number of comparisons (known as a Bonferroni correction). Therefore, in a study of 10 variants, one would need to obtain a p-value of 0.005 to have the equivalent of a 5\% type I error rate. However, the Bonferroni correction can be overly conservative if the multiple tests correspond to correlated variables. For example, phenotypes are often correlated (e.g., asthma and IgE levels) as are the genotypes of single nucleotide polymorphisms (SNPs) that are in LD. Thus, these comparisons do not represent independent tests and the Bonferroni correction can be extreme in these circumstances. In fact, the Bonferonni correction can be conservative even for independent tests [8]. Because there is no simple correction for multiple correlated comparisons, alternative methods to correct for the error rates are used. Permutation tests are useful because they preserve the correlation structure of the data and provide accurate p-values. They can be used to control the probability of committing any type 1 error and this can lead to stringent thresholds in studies with a large number of candidate genes. An alternative approach is to control the False Discovery Rate (FDR) [9], which is the proportion of false positives in the set of rejected hypotheses. FDR is a more liberal rate to control, so it is more powerful.

Type I errors can also result from genotyping errors, particularly if there is a systematic error such as overcalling one genotype over another. This is particularly worrisome in case-control studies in unrelated individuals because Mendelian error checks cannot be performed as they can for family studies. One way to minimize this is to make sure that the genotypes in the cases and controls are in
Hardy-Weinberg proportions. Systematic errors in genotyping will often yield genotype frequencies that are not in Hardy-Weinberg proportions. In fact, there are a surprisingly large number of published associations that either did not check for Hardy-Weinberg equilibrium or presented data that were not in Hardy-Weinberg proportions [10]. When published association studies of a variety of diseases were re-examined, $12 \%$ of the 133 SNPs reported were not in Hardy-Weinberg equilibrium in the controls, suggesting genotyping error. Further, the proportion of SNPs that deviated from equilibrium was higher among the SNPs for which a positive association was reported [10]. Some of these markers were not identified by the authors as showing deviations from equilibrium. One explanation for this could be that they used an incorrect test of significance, which may not be uncommon (e.g. $[11,12])$. In particular, for a biallelic marker with three genotypes (such as for SNPs), the significance testing for Hardy-Weinberg equilibrium is based on a 1-degree of freedom test. On the other hand, markers showing departure from Hardy-Weinberg equilibrium should not be automatically discarded because deviation from HardyWeinberg equilibrium among cases is expected for variants close to a susceptibility locus under many genetic models [13-15]. Nevertheless, markers that show deviations from expectations should be closely scrutinized and retyped to ensure that they are genotyped correctly. Lastly, type I errors can result from population substructure, or sampling cases and controls that differ with respect to ethnic background. Because allele frequencies vary among ethnic groups, great care must be taken to assure that case and control subjects have similar ethnic compositions. If they differ, an allele may be significantly more frequent in the cases compared with controls due to differences in ethnicity, but this may be misinterpreted as an association with the disease. Methods are now available to directly test for stratification and to correct for any imbalances $[16,17]$, but these require genotyping the case and control samples for 30 or more informative loci (i.e., loci that discriminate between pairs of racial or ethnic groups [17]). Another approach to address the problem of population admixture is to conduct family-based association studies with analytical methods that are robust to population admixture, such as the transmission disequilibrium test (TDT) [18]. These methods have become increasingly popular in genetic studies of complex disorders, although they are uniformly less powerful than studying an equivalent number of unrelated cases and controls.

Not all associations that are not replicated are false positive results. An association may not be replicated because of different patterns of LD in different populations. Differences in LD patterns can be caused by differences in allele frequencies and/or the presence of more than one causal variant. Although there are no examples of this, it remains 
a theoretical possibility. This can be addressed by examining haplotypes instead of single SNPs. Many studies have now shown that examining multiple SNPs as haplotypes is often preferable to single SNP analysis $[19,20]$. A haplotype is composed of alleles at different loci that are inherited together on the same chromosome. Thus, even if the disease-causing variant itself is not identified, a shared haplotype that contains the disease variant will be more common in cases than in controls. This could in addition help to identify the true susceptibility variant. On the other hand, an association may not be replicated because the phenotype is defined differently between studies. For example, the phenotype "atopy" has been defined as a positive skin prick test [SPT], a positive RAST test, high total serum IgE, or a combination of these tests. Although these phenotypes are clearly related, it is likely that some genes that influence total IgE levels do not influence specific IgE response to allergens, and vice versa.

Lastly, positive associations may not be replicated because the true model of genetic susceptibility for diseases such as asthma and atopy is complex. It is most likely that any particular susceptibility variant has a relatively minor effect on the phenotype and that the magnitude of its effect will be influenced by genes at other loci (gene-gene interactions) [21,22] and by the environmental factors (gene-environment interactions) [23-25]. In fact, some variants may only confer susceptibility in combination with other genes (epistasis) or in certain environments. Because background genes and environmental factors differ between populations it would not be surprising if associations with single SNPs or haplotypes differed between populations.

\section{Review of the association study literature}

We searched the public databases for published candidate gene association studies of asthma and related phenotypes, using keywords "association" or "case-control" together with each of the following: "asthma", "bronchial hyperresponsiveness", "BHR", "atopy", "SPT", "atopic dermatitis", "IgE", and "drug response". We identified 199 studies with at least one significant association reported. These studies identified 64 genes as potential susceptibility loci. We then searched for all other association studies with variants in these 64 genes (Table 1 [see Additional file 1]). For this analysis, we considered an initial association replicated if at least one other study found an association with variation in the same gene, but not necessarily with the same variant. Using these criteria, 33 gene associations were replicated and 9 associations were not replicated either in a second study or in a second sample in the same study. Additionally, 22 genetic associations were only reported in a single study, i.e. replication studies have not been published, even though it is likely that at least some have been performed. In this regard, the establishment of a database of non-significant candidate gene studies would helpful for prioritizing genes for genetic studies and would therefore benefit the asthma genetics community overall. Nonetheless, the results of this survey underline the potential for a great amount of heterogeneity underlying asthma. However, many of these studies have been conducted in small samples ( $<100$ cases and controls), few correct for multiple testing, and in many cases, replication studies were performed in different ethnic groups than those studied in the original report. Lastly, in only $34.8 \%$ of studies, all markers were reported to be in Hardy-Weinberg equilibrium, while in $2.2 \%$ of studies at least one marker was reported to deviate from equilibrium, and in the majority of studies (63 $\%)$ testing for Hardy-Weinberg proportions was not mentioned at all.

Regardless of these caveats, some genes stand out because they were associated with asthma-phenotypes rather consistently across studies and populations. In particular, variation in eight genes have been associated with asthmaphenotypes in five or more studies: interleukin-4 (IL4), interleukin-13 (IL13), $\beta 2$ adrenergic receptor (ADRB2), human leukocyte antigen DRB1 (HLA-DRB1), tumor necrosis factor $(T N F)$, lymphotoxin-alpha (LTA), highaffinity IgE receptor (FCER1B) and IL-4 receptor (IL4RA). These loci likely represent true asthma or atopy susceptibility loci or genes important for disease modification. An example of the latter is the ADRB2 gene, which has been more consistently associated with asthma severity than with asthma or atopy per se.

\section{Conclusions}

Variants in 64 genes have been associated with asthma or atopy phenotypes in at least one study, although many of these studies are methodologically limited and need replication. In the future, association studies incorporating gene-gene and gene-environment interactions may help to disentangle some of the complexities of these diseases and explain some of the discrepant results. Lastly, the development of guidelines for establishing appropriate thresholds for significance in association studies would impose more rigorous standards on candidate gene studies, similar to what is now standard for linkage studies [26], and the creation of a database for unpublished association studies would be helpful for evaluating the overall evidence for association of asthma or atopy candidate genes.

\section{List of abbreviations}

$\mathrm{AD}$ atopic dermatitis

Alt a Alternaria alternata

Amb a Ambrosia artemisiifolia (short ragweed pollen) 
Bet $v$ Betula verucosa (birch pollen)

BHR bronchial hyperresponsiveness

Can $f$ Canis familiaris (dog allergen)

Der $p$ Dermatophagoides pteronyssinus (house dust mite allergen)

FDR false discovery rate

Fel $d$ Felis domesticus (cat allergen)

$\mathrm{FEV}_{1}$ forced exspiratory volume in the first second

FVC forced vital capacity

HDM house dust mite

IgE immunoglobulin E

LD linkage disequilibrium

Lol $p$ Lolium perenne (rye grass pollen)

Ole e Olea Europaea (olive pollen)

Par o Parietaria officinalis

Phl p Phleum pratense (Timothy grass pollen)

SNP single nucleotide polymorphism

SPT skin prick test

RAST radio allergo sorbent test

TDT transmission disequilibrium test

\section{Authors' contributions}

This manuscript was written by all three co-authors; S.H. performed the literature review and summary table.

\section{Additional material}

\section{Additional File 1}

Genes that have been associated with asthma-or atopy-related traits in at least one study. We searched the public databases for published candidate gene association studies of asthma and related phenotypes and list all genes that have been associated with asthma-or atopy-related traits in at least one study. For each variant in these 64 genes, we report the associated phenotype(s), information about study population, sample size, and Hardy-Weinberg testing results for each study.

Click here for file

[http://www.biomedcentral.com/content/supplementary/1465-

9921-4-14-S1.doc]

\section{Acknowledgements}

The authors gratefully acknowledge Janette Coffey, April Chan and Susan Costello for clerical assistance. This work was supported in part by NIH grants HL56399, HL66533, HL7083I, and HL724I 4; S.H. was supported in part by the Deutsche Forschungsgesellschaft.

\section{References}

I. Cookson WO: Asthma genetics. Chest 2002, I 2 I:7S-I3S.

2. Hakonarson $\mathrm{H}, \mathrm{W}$ jst $\mathrm{M}$ : Current concepts on the genetics of asthma. Curr Opin Pediatr 200I, I 3:267-277.

3. Hoffjan S, Ober C: Present status on the genetic studies of asthma. Curr Opin Immunol 2002, I4:709-7I7.

4. Risch N, Merikangas K: The future of genetic studies of complex human diseases. Science 1996, 273:1516-1517.

5. Weiss ST: Association studies in asthma genetics. Am J Respir Crit Care Med 200I, I 64:2014-20I5.

6. Kruglyak L: Prospects for whole-genome linkage disequilibrium mapping of common disease genes. Nat Genet 1999, 22:139-144.

7. Shifman S, Kuypers J, Kokoris M, Yakir B, Darvasi A: Linkage disequilibrium patterns of the human genome across populations. Hum Mol Genet 2003, I 2:771-776.

8. Schwager S]: Bonferroni sometimes loses. Am Stat 1984, 38: $192-197$.

9. Benjamini $Y$, Hochberg $M$ : Controlling the false discovery rate: a practical and powerful approach to multiple testing. Journal of the Royal Statistical Society 1995, 57:289-300.

10. Xu J, Turner A, Little J, Bleecker ER, Meyers DA: Positive results in association studies are associated with departure from Hardy-Weinberg equilibrium: hint for genotyping error? Hum Genet 2002, I I I:573-574.

II. Ozaki K, Ohnishi Y, lida A, Sekine A, Yamada R, Tsunoda T, Sato E, Sato H, Hori M, Nakamura $Y$ et al.: Functional SNPs in the lymphotoxin-alpha gene that are associated with susceptibility to myocardial infarction. Nat Genet 2003, 32:650-654.

12. Brody LC, Conley M, Cox C, Kirke PN, McKeever MP, Mills JL, Molloy AM, O'Leary VB, Parle-McDermott A, Scott JM et al.: A polymorphism, R653Q, in the trifunctional enzyme methylenetetrahydrofolate dehydrogenase/methenyltetrahydrofolate cyvlohydrolase/formyltetrahydrofolate synthetase is a maternal genetic risk factor for neural tube defects: report of the Birth Defects Research Group. Am J Hum Genet 2002, 71:1207-1215.

13. Nielsen DM, Ehm MG, Weir BS: Detecting Marker-Disease Association by Testing for Hardy-Weinberg Disequilibrium at a Marker Locus. Am J Hum Genet 1999, 63: I53 I-I540.

14. Wittke JK, Cox NJ: Departures from Hardy-Weinberg equilibrium for common disease models. Am J Hum Genet 2003, 73S:620.

15. Lee WC: Searching for disease-susceptibility loci by testing for Hardy-Weinberg disequilibrium in a gene bank of affected individuals. Am J Epidemiol 2003, I 58:397-400.

16. Devlin B, Roeder K: Genomic control for association studies. Biometrics 1999, 55:997-1004. 
17. Pritchard JK, Rosenberg NA: Use of unlinked genetic markers to detect population stratification in association studies. $\mathrm{Am} J$ Hum Genet 1999, 65:220-228.

18. Spielman RS, Ewens WJ: The TDT and other family-based tests for linkage disequilibrium and association. Am J Hum Genet 1996, 59:983-989.

19. Ober C, Leavitt SA, Tsalenko A, Howard TD, Hoki DM, Daniel R, Newman DL, Wu X, Parry R, Lester LA et al.: Variation in the interleukin 4-receptor alpha gene confers susceptibility to asthma and atopy in ethnically diverse populations. Am J Hum Genet 2000, 66:517-526.

20. Drysdale CM, McGraw DW, Stack CB, Stephens JC, Judson RS, Nandabalan K, Arnold K, Ruano G, Liggett SB: Complex promoter and coding region beta 2 -adrenergic receptor haplotypes alter receptor expression and predict in vivo responsiveness. Proc Natl Acad Sci U S A 2000, 97:10483-10488.

21. Howard TD, Koppelman GH, Xu J, Zheng SL, Postma DS, Meyers DA, Bleecker ER: Gene-gene interaction in asthma: IL4RA and ILI 3 in a Dutch population with asthma. Am J Hum Genet 2002, 70:230-236.

22. Bottini N, Mao XQ, Borgiani P, Saccucci P, Stefanini L, Greco E, Fontana L, Shirakawa T, Hopkin JM: Low molecular weight PTP-IL4RA interaction in atopy predisposition. Allergy 2002, 57:10-12.

23. Baldini M, Vercelli D, Martinez FD: CD I 4: an example of gene by environment interaction in allergic disease. Allergy 2002, 57: $188-192$

24. Colilla S, Nicolae D, Pluzhnikov A, Blumenthal MN, Beaty TH, Bleecker ER, Lange EM, Rich SS, Meyers DA, Ober C et al.: Evidence for gene-environment interactions in a linkage study of asthma and smoking exposure. J Allergy Clin Immunol 2003, I I I:840-846.

25. Werner M, Topp R, Wimmer K, Richter K, Bischof W, Wjst M, Heinrich J: TLR4 gene variants modify endotoxin effects on asthma. J Allergy Clin Immunol 2003, I I 2:323-330.

26. Lander E, Kruglyak L: Genetic dissection of complex traits: guidelines for interpreting and reporting linkage results. Nat Genet 1995, I I:24I-247.

27. Bourgain C, Hoffjan S, Nicolae R, Newman D, Steiner L, Walker K, Reynolds R, Ober C, McPeek MS: Novel case-control test in a founder population identifies p-selectin as an atopy susceptibility locus. Am J Hum Genet 2003, 73:6I2-626.

28. Rosenwasser L): Promoter polymorphism in the candidate genes, IL-4, IL-9, TGF-betal, for atopy and asthma. Int Arch Allergy Immunol 1999, I I 8:268-270.

29. Hobbs K, Negri J, Klinnert M, Rosenwasser LJ, Borish L: Interleukin10 and transforming growth factor-beta promoter polymorphisms in allergies and asthma. Am J Respir Crit Care Med 1998, 158:1958-1962.

30. Unoki M, Furuta S, Onouchi Y, Watanabe O, Doi S, Fujiwara H, Miyatake A, Fujita K, Tamari M, Nakamura Y: Association studies of 33 single nucleotide polymorphisms (SNPs) in 29 candidate genes for bronchial asthma: positive association a T924C polymorphism in the thromboxane $\mathbf{A} 2$ receptor gene. Hum Genet 2000, 106:440-446.

31. Immervoll T, Loesgen S, Dutsch G, Gohlke H, Herbon N, Klugbauer $\mathrm{S}$, Dempfle A, Bickeboller H, Becker-Follmann J, Ruschendorf F et al.: Fine mapping and single nucleotide polymorphism association results of candidate genes for asthma and related phenotypes. Hum Mutat 200I, 18:327-336.

32. Hakonarson H, Bjornsdottir US, Ostermann E, Arnason T, Adalsteinsdottir AE, Halapi E, Shkolny D, Kristjansson K, Gudnadottir SA, Frigge $M L$ et al:: Allelic frequencies and patterns of singlenucleotide polymorphisms in candidate genes for asthma and atopy in Iceland. Am J Respir Crit Care Med 200I, 164:2036-2044.

33. Karjalainen J, Hulkkonen J, Nieminen MM, Huhtala H, Aromaa A, Klaukka T, Hurme M: Interleukin- 10 gene promoter region polymorphism is associated with eosinophil count and circulating immunoglobulin E in adult asthma. Clin Exp Allergy 2003, 33:78-83.

34. Donfack J, Kogut P, Forsythe S, Solway J, Ober C: Sequence variation in the promoter region of the cholinergic receptor muscarinic 3 gene and asthma and atopy. J Allergy Clin Immunol 2003, I I I:527-532.

35. Mao XQ, Kawai M, Yamashita T, Enomoto T, Dake $Y$, Sasaki $S$, Kataoka Y, Fukuzumi T, Endo K, Sano H et al:: Imbalance produc- tion between interleukin-I beta (IL-I beta) and IL-I receptor antagonist (IL-IRa) in bronchial asthma. Biochem Biophys Res Commun 2000, 276:607-612.

36. Karjalainen J, Hulkkonen J, Pessi T, Huhtala H, Nieminen MM, Aromaa A, Klaukka T, Hurme M: The ILIA genotype associates with atopy in nonasthmatic adults. J Allergy Clin Immunol 2002, I I 0:429-434.

37. Karjalainen J, Nieminen MM, Aromaa A, Klaukka T, Hurme M: The IL-I beta genotype carries asthma susceptibility only in men. J Allergy Clin Immunol 2002, 109:5 I4-5I6.

38. Yan L, Galinsky RE, Bernstein JA, Liggett SB, Weinshilboum RM: Histamine $\mathbf{N}$-methyltransferase pharmacogenetics: association of a common functional polymorphism with asthma. Pharmacogenetics 2000, 10:261-266.

39. Sasaki Y, Ihara K, Ahmed S, Yamawaki K, Kusuhara K, Nakayama $\mathrm{H}$, Nishima S, Hara T: Lack of association between atopic asthma and polymorphisms of the histamine $\mathrm{HI}$ receptor, histamine H2 receptor, and histamine $\mathrm{N}$-methyltransferase genes. Immunogenetics 2000, 5 I:238-240.

40. Ligers A, Teleshova N, Masterman T, Huang WX, Hillert J: CTLA-4 gene expression is influenced by promoter and exon I polymorphisms. Genes Immun 200I, 2: I 45-I52.

41. Heinzmann A, Plesnar C, Kuehr J, Forster J, Deichmann KA: Common polymorphisms in the CTLA-4 and CD28 genes at 2q33 are not associated with asthma or atopy. Eur J Immunogenet 2000, 27:57-6I.

42. Nakao F, Ihara K, Ahmed S, Sasaki Y, Kusuhara K, Takabayashi A, Nishima S, Hara T: Lack of association between CD28/CTLA-4 gene polymorphisms and atopic asthma in the Japanese population. Exp Clin Immunogenet 2000, I7: 179- I84.

43. Hizawa N, Yamaguchi E, Jinushi E, Konno S, Kawakami Y, Nishimura M: Increased total serum IgE levels in patients with asthma and promoter polymorphisms at CTLA4 and FCERIB. J Allergy Clin Immunol 200I, I 08:74-79.

44. Lee SY, Lee YH, Shin C, Shim JJ, Kang KH, Yoo SH, In KH: Association of asthma severity and bronchial hyperresponsiveness with a polymorphism in the cytotoxic T-lymphocyte antigen4 gene. Chest 2002, 122:17I-176.

45. Maurer M, Loserth S, Kolb-Maurer A, Ponath A, Wiese S, Kruse N, Rieckmann P: A polymorphism in the human cytotoxic T-lymphocyte antigen 4 (CTLA4) gene (exon I +49) alters T-cell activation. Immunogenetics 2002, 54:1-8.

46. Howard TD, Postma DS, Koppelman GA, Koppelman GH, Zheng SL, Wysong AK, Xu J, Meyers DA, Bleecker ER: Fine mapping of an IgE-controlling gene on chromosome 2q: Analysis of CTLA4 and CD28. J Allergy Clin Immunol 2002, I I 0:743-75I.

47. Fukunaga K, Asano K, Mao XQ, Gao PS, Roberts MH, Oguma T, Shiomi T, Kanazawa M, Adra CN, Shirakawa T et al:: Genetic polymorphisms of CC chemokine receptor 3 in Japanese and British asthmatics. Eur Respir J 200I, 17:59-63.

48. Liu R, Paxton WA, Choe S, Ceradini D, Martin SR, Horuk R, MacDonald ME, Stuhlmann H, Koup RA, Landau NR: Homozygous defect in HIV-I coreceptor accounts for resistance of some multiply-exposed individuals to HIV-I infection. Cell 1996, 86:367-377.

49. Hall IP, Wheatley A, Christie G, McDougall C, Hubbard R, Helms PJ: Association of CCR5 delta32 with reduced risk of asthma. Lancet 1999, 354:1264-1265.

50. Mitchell TJ, Walley AJ, Pease JE, Venables PJ, Wiltshire S, Williams TJ, Cookson WO: Delta 32 deletion of CCR5 gene and association with asthma or atopy. Lancet 2000, 356: $149 \mid-1492$.

5I. Szalai C, Bojszko A, Beko G, Falus A: Prevalence of CCR5delta32 in allergic diseases. Lancet 2000, 355:66.

52. Sandford AJ, Zhu S, Bai TR, Fitzgerald JM, Pare PD: The role of the C-C chemokine receptor-5 Delta32 polymorphism in asthma and in the production of regulated on activation, normal T cells expressed and secreted. J Allergy Clin Immunol 200I, 108:69-73.

53. Nagy A, Kozma GT, Bojszko A, Krikovszky D, Falus A, Szalai C: No association between asthma or allergy and the CCR5Delta 32 mutation. Arch Dis Child 2002, 86:426.

54. McGinnis R, Child F, Clayton S, Davies S, Lenney W, Illig T, Wjst M, Spurr N, Debouck C, Hajeer AH et al.: Further support for the association of CCR5 allelic variants with asthma susceptibility. Eur J Immunogenet 2002, 29:525-528. 
55. Srivastava P, Helms PJ, Stewart D, Main M, Russell G: Association of CCR5Delta32 with reduced risk of childhood but not adult asthma. Thorax 2003, 58:222-226.

56. Lazarus R, Klimecki WT, Raby BA, Vercelli D, Palmer LJ, Kwiatkowski DJ, Silverman EK, Martinez F, Weiss ST: Single-nucleotide polymorphisms in the Toll-like receptor 9 gene (TLR9): frequencies, pairwise linkage disequilibrium, and haplotypes in three U.S. ethnic groups and exploratory case-control disease association studies(small star, filled). Genomics 2003, 8I:85-9I.

57. Kirkbride HJ, Bolscher JG, Nazmi K, Vinall LE, Nash MW, Moss FM, Mitchell DM, Swallow DM: Genetic polymorphism of MUC7: allele frequencies and association with asthma. Eur I Hum Genet 200I, 9:347-354.

58. Noguchi E, Shibasaki M, Kamioka M, Yokouchi Y, Yamakawa-Kobayashi K, Hamaguchi H, Matsui A, Arinami T: New polymorphisms of haematopoietic prostaglandin $D$ synthase and human prostanoid DP receptor genes. Clin Exp Allergy 2002, 32:93-96.

59. Mao XQ, Gao PS, Roberts MH, Enomoto T, Kawai M, Sasaki S, Shaldon SR, Coull P, Dake Y, Adra CN et al:: Variants of endothelin$I$ and its receptors in atopic asthma. Biochem Biophys Res Commun 1999, 262:259-262.

60. Nishio Y, Noguchi E, Ito S, Ichikawa E, Umebayashi Y, Otsuka F, Arinami $\mathrm{T}$ : Mutation and association analysis of the interferon regulatory factor 2 gene (IRF2) with atopic dermatitis. J Hum Genet 200I, 46:664-667.

61. Rohrbach M, Frey U, Kraemer R, Liechti-Gallati S: A variant in the gene for GM-CSF, II I 7T, is associated with atopic asthma in a Swiss population of asthmatic children. J Allergy Clin Immunol 1999, 104:247-248.

62. He JQ, Ruan J, Chan-Yeung M, Becker AB, Dimich-Ward H, Pare PD, Sandford A): Polymorphisms of the GM-CSF genes and the development of atopic diseases in at-risk children. Chest 2003, I 23:438S.

63. Nakao F, Ihara K, Kusuhara K, Sasaki Y, Kinukawa N, Takabayashi A, Nishima S, Hara T: Association of IFN-gamma and IFN regulatory factor I polymorphisms with childhood atopic asthma. J Allergy Clin Immunol 200I, 107:499-504.

64. Rosenwasser LJ, Klemm DJ, Dresback JK, Inamura H, Mascali JJ, Klinnert M, Borish L: Promoter polymorphisms in the chromosome 5 gene cluster in asthma and atopy. Clin Exp Allergy 1995, 25(Suppl 2):74-78. discussion 95-76

65. Walley AJ, Cookson WO: Investigation of an interleukin-4 promoter polymorphism for associations with asthma and atopy. J Med Genet 1996, 33:689-692.

66. Kawashima T, Noguchi E, Arinami T, Yamakawa-Kobayashi K, Nakagawa $H$, Otsuka $F$, Hamaguchi $H$ : Linkage and association of an interleukin 4 gene polymorphism with atopic dermatitis in Japanese families. J Med Genet 1998, 35:502-504.

67. Noguchi E, Shibasaki M, Arinami T, Takeda K, Yokouchi Y, Kawashima $T$, Yanagi $\mathrm{H}$, Matsui A, Hamaguchi $\mathrm{H}$ : Association of asthma and the interleukin-4 promoter gene in Japanese. Clin Exp Allergy 1998, 28:449-453.

68. Burchard EG, Silverman EK, Rosenwasser LJ, Borish L, Yandava C, Pillari A, Weiss ST, Hasday J, Lilly CM, Ford JG et al:: Association between a sequence variant in the IL-4 gene promoter and FEV(I) in asthma. Am J Respir Crit Care Med 1999, 160:919-922.

69. Ober C, Tsalenko A, Parry R, Cox NJ: A second-generation genomewide screen for asthma-susceptibility alleles in a founder population. Am J Hum Genet 2000, 67: I I 54-1 I62

70. Zhu S, Chan-Yeung M, Becker AB, Dimich-Ward H, Ferguson AC, Manfreda J, Watson WT, Pare PD, Sandford A): Polymorphisms of the IL-4, TNF-alpha, and Fcepsilon RIbeta genes and the risk of allergic disorders in at-risk infants. Am J Respir Crit Care Med 2000, 161:1655-1659.

7I. Takabayashi A, Ihara K, Sasaki Y, Suzuki Y, Nishima S, Izuhara K, Hamasaki N, Hara T: Childhood atopic asthma: positive association with a polymorphism of IL-4 receptor alpha gene but not with that of IL-4 promoter or Fc epsilon receptor I beta gene. Exp Clin Immunogenet 2000, 1 7:63-70.

72. Sandford AJ, Chagani T, Zhu S, Weir TD, Bai TR, Spinelli JJ, Fitzgerald JM, Behbehani NA, Tan WC, Pare PD: Polymorphisms in the IL4, IL4RA, and FCERIB genes and asthma severity. J Allergy Clin Immunol 2000, 106:।35- |40.

73. Elliott K, Fitzpatrick E, Hill D, Brown J, Adams S, Chee P, Stewart G, Fulcher $D$, Tang $M$, Kemp A et al.: The $\mathbf{- 5 9 0 C / T}$ and $\mathbf{- 3 4 C / T}$ interleukin-4 promoter polymorphisms are not associated with atopic eczema in childhood. I Allergy Clin Immunol 200I, 108:285-287.

74. Tanaka K, Sugiura H, Uehara M, Hashimoto Y, Donnelly C, Montgomery DS: Lack of association between atopic eczema and the genetic variants of interleukin-4 and the interleukin-4 receptor alpha chain gene: heterogeneity of genetic backgrounds on immunoglobulin E production in atopic eczema patients. Clin Exp Allergy 200I, 31:1522-1527.

75. Novak N, Kruse S, Kraft S, Geiger E, Kluken H, Fimmers R, Deichmann KA, Bieber T: Dichotomic nature of atopic dermatitis reflected by combined analysis of monocyte immunophenotyping and single nucleotide polymorphisms of the interleukin-4/interleukin- 13 receptor gene: the dichotomy of extrinsic and intrinsic atopic dermatitis. J Invest Dermatol 2002, I I 9:870-875.

76. Suzuki I, Hizawa N, Yamaguchi E, Kawakami Y: Association between a C+33T polymorphism in the IL-4 promoter region and total serum IgE levels. Clin Exp Allergy 2000, 30:1746-1749.

77. Noguchi E, Nukaga-Nishio Y, Jian Z, Yokouchi Y, Kamioka M, Yamakawa-Kobayashi K, Hamaguchi H, Matsui A, Shibasaki M, Arinami T: Haplotypes of the $5^{\prime}$ region of the IL-4 gene and SNPs in the intergene sequence between the IL- 4 and IL- I 3 genes are associated with atopic asthma. Hum Immunol 200I, 62: $125 \mid-1257$.

78. van der Pouw Kraan TC, van Veen A, Boeije LC, van Tuyl SA, de Groot ER, Stapel SO, Bakker A, Verweij CL, Aarden LA, van der Zee JS: An IL-13 promoter polymorphism associated with increased risk of allergic asthma. Genes Immun I999, I:6I-65.

79. Howard TD, Whittaker PA, Zaiman AL, Koppelman GH, Xu J, Hanley MT, Meyers DA, Postma DS, Bleecker ER: Identification and association of polymorphisms in the interleukin-13 gene with asthma and atopy in a Dutch population. Am J Respir Cell Mol Biol 200I, 25:377-384.

80. Tsunemi Y, Saeki H, Nakamura K, Sekiya T, Hirai K, Kakinuma T, Fujita $H$, Asano N, Tanida $Y$, Wakugawa $M$ et al: Interleukin-13 gene polymorphism G4257A is associated with atopic dermatitis in Japanese patients. J Dermatol Sci 2002, 30:100-107.

8I. Arima K, Umeshita-Suyama R, Sakata $Y$, Akaiwa M, Mao XQ, Enomoto T, Dake $\mathrm{Y}$, Shimazu S, Yamashita T, Sugawara N et al:: Upregulation of IL- 13 concentration in vivo by the ILI 3 variant associated with bronchial asthma. J Allergy Clin Immunol 2002, 109:980-987.

82. Liu X, Nickel R, Beyer K, Wahn U, Ehrlich E, Freidhoff LR, Bjorksten $B$, Beaty TH, Huang SK: An ILI 3 coding region variant is associated with a high total serum IgE level and atopic dermatitis in the German multicenter atopy study (MAS-90). J Allergy Clin Immunol 2000, 106:167-170.

83. Graves PE, Kabesch M, Halonen M, Holberg CJ, Baldini M, Fritzsch C, Weiland SK, Erickson RP, von Mutius E, Martinez FD: A cluster of seven tightly linked polymorphisms in the IL-I 3 gene is associated with total serum IgE levels in three populations of white children. I Allergy Clin Immunol 2000, 105:506-5I3.

84. Heinzmann A, Mao XQ, Akaiwa M, Kreomer RT, Gao PS, Ohshima K, Umeshita R, Abe Y, Braun S, Yamashita T et al.: Genetic variants of IL-I 3 signalling and human asthma and atopy. Hum Mol Genet 2000, 9:549-559.

85. Leung TF, Tang NL, Chan IH, Li AM, Ha G, Lam CW: A polymorphism in the coding region of interleukin- 13 gene is associated with atopy but not asthma in Chinese children. Clin Exp Allergy 200I, 31:1515-1521.

86. Celedon JC, Soto-Quiros ME, Palmer LJ, Senter J, Mosley J, Silverman EK, Weiss ST: Lack of association between a polymorphism in the interleukin- 13 gene and total serum immunoglobulin $E$ level among nuclear families in Costa Rica. Clin Exp Allergy 2002, 32:387-390.

87. DeMeo DL, Lange C, Silverman EK, Senter JM, Drazen JM, Barth MJ, Laird N, Weiss ST: Univariate and multivariate family-based association analysis of the IL-I 3 ARG I 30 GLN polymorphism in the Childhood Asthma Management program. Genet Epidemiol 2002, 23:335-348.

88. LeVan TD, Bloom JW, Bailey TJ, Karp CL, Halonen M, Martinez FD, Vercelli $D$ : A common single nucleotide polymorphism in the CDI 4 promoter decreases the affinity of Sp protein binding and enhances transcriptional activity. I Immunol 2001, 167:5838-5844. 
89. Baldini M, Lohman IC, Halonen M, Erickson RP, Holt PG, Martinez FD: A Polymorphism* in the 5' flanking region of the CDI4 gene is associated with circulating soluble CDI4 levels and with total serum immunoglobulin E. Am J Respir Cell Mol Biol I999, 20:976-983.

90. Gao PS, Mao XQ, Baldini M, Roberts MH, Adra CN, Shirakawa T, Holt PG, Martinez FD, Hopkin JM: Serum total IgE levels and CDI4 on chromosome 5q3 I. Clin Genet 1999, 56:I64-I65.

91. Koppelman GH, Reijmerink NE, Colin Stine O, Howard TD, Whittaker PA, Meyers DA, Postma DS, Bleecker ER: Association of a promoter polymorphism of the CDI4 gene and atopy. $A m$ J Respir Crit Care Med 200I, I 63:965-969.

92. Cardaba B, Moffatt MF, Fernandez E, Jurado A, Rojo M, Garcia M, Ansotegui IJ, Cortegano I, Arrieta I, Etxenagusia MA et al.: Allergy to dermatophagoides in a group of Spanish gypsies: genetic restrictions. Int Arch Allergy Immunol 200 I, I 25:297-306.

93. Sengler C, Haider A, Sommerfeld C, Lau S, Baldini M, Martinez F, Wahn U, Nickel R: Evaluation of the CDI4 C-I59 T polymorphism in the German Multicenter Allergy Study cohort. Clin Exp Allergy 2003, 33:166-169.

94. Niimi T, Munakata M, Keck-Waggoner CL, Popescu NC, Levitt RC, Hisada $M$, Kimura S: A polymorphism in the human UGRPI gene promoter that regulates transcription is associated with an increased risk of asthma. Am J Hum Genet 2002, 70:718-725.

95. Morahan G, Huang D, Wu M, Holt BJ, White GP, Kendall GE, Sly PD, Holt PG: Association of ILI 2B promoter polymorphism with severity of atopic and non-atopic asthma in children. Lancet 2002, 360:455-459.

96. Morahan G, Huang D, Ymer SI, Cancilla MR, Stephen K, Dabadghao P, Werther G, Tait BD, Harrison LC, Colman PG: Linkage disequilibrium of a type I diabetes susceptibility locus with a regulatory ILI 2B allele. Nat Genet 200I, 27:218-22I.

97. Tsunemi Y, Saeki H, Nakamura K, Sekiya T, Hirai K, Fujita H, Asano N, Kishimoto $M$, Tanida $Y$, Kakinuma $T$ et al.: Interleukin- I 2 p40 gene (ILI 2B) 3'-untranslated region polymorphism is associated with susceptibility to atopic dermatitis and psoriasis vulgaris. J Dermatol Sci 2002, 30: I6I-I66.

98. Noguchi E, Yokouchi Y, Shibasaki M, Kamioka M, Yamakawa-Kobayashi K, Matsui A, Arinami T: Identification of missense mutation in the ILI2B gene: lack of association between ILI2B polymorphisms and asthma and allergic rhinitis in the Japanese population. Genes Immun 200I, 2:40I-403.

99. Green SA, Turki J, Bejarano P, Hall IP, Liggett SB: Influence of beta 2-adrenergic receptor genotypes on signal transduction in human airway smooth muscle cells. Am J Respir Cell Mol Biol 1995, I 3:25-33.

100. Reihsaus E, Innis M, Maclntyre N, Liggett SB: Mutations in the gene encoding for the beta 2 -adrenergic receptor in normal and asthmatic subjects. Am J Respir Cell Mol Biol 1993, 8:334-339.

I0I. Turki J, Pak J, Green SA, Martin RJ, Liggett SB: Genetic polymorphisms of the beta 2-adrenergic receptor in nocturnal and nonnocturnal asthma. Evidence that Gly 16 correlates with the nocturnal phenotype. J Clin Invest 1995, 95:I635-I64I.

102. Dewar JC, Wilkinson J, Wheatley A, Thomas NS, Doull I, Morton N, Lio P, Harvey JF, Liggett SB, Holgate ST et al:: The glutamine 27 beta2-adrenoceptor polymorphism is associated with elevated IgE levels in asthmatic families. J Allergy Clin Immunol I997, I 00:26I-265.

103. Tan S, Hall IP, Dewar J, Dow E, Lipworth B: Association between beta 2-adrenoceptor polymorphism and susceptibility to bronchodilator desensitisation in moderately severe stable asthmatics. Lancet 1997, 350:995-999.

104. Martinez FD, Graves PE, Baldini M, Solomon S, Erickson R: Association between genetic polymorphisms of the beta2-adrenoceptor and response to albuterol in children with and without a history of wheezing. I Clin Invest 1997, I 00:3 I84-3 I88.

105. Hopes E, McDougall C, Christie G, Dewar J, Wheatley A, Hall IP, Helms PJ: Association of glutamine 27 polymorphism of beta 2 adrenoceptor with reported childhood asthma: population based study. Bmj 1998, 3 16:664.

106. Deichmann KA, Schmidt A, Heinzmann A, Kruse S, Forster J, Kuehr $\mathrm{J}$ : Association studies on beta2-adrenoceptor polymorphisms and enhanced IgE responsiveness in an atopic population. Clin Exp Allergy 1999, 29:794-799.
107. Kotani Y, Nishimura Y, Maeda H, Yokoyama M: Beta2-adrenergic receptor polymorphisms affect airway responsiveness to salbutamol in asthmatics. J Asthma 1999, 36:583-590.

108. Lipworth BJ, Hall IP, Aziz I, Tan KS, Wheatley A: Beta2-adrenoceptor polymorphism and bronchoprotective sensitivity with regular short- and long-acting beta2-agonist therapy. Clin $\mathrm{Sci}$ (Lond) 1999, 96:253-259.

109. Taylor DR, Hancox RJ, McRae W, Cowan JO, Flannery EM, McLachlan $\mathrm{CR}$, Herbison GP: The influence of polymorphism at position 16 of the beta2-adrenoceptor on the development of tolerance to beta-agonist. J Asthma 2000, 37:691-700.

110. Summerhill E, Leavitt SA, Gidley H, Parry R, Solway J, Ober C: beta(2)-adrenergic receptor Arg I 6/Arg 16 genotype is associated with reduced lung function, but not with asthma, in the Hutterites. Am J Respir Crit Care Med 2000, 162:599-602.

I I I. Israel E, Drazen JM, Liggett SB, Boushey HA, Cherniack RM, Chinchilli VM, Cooper DM, Fahy JV, Fish JE, Ford JG et al.: Effect of polymorphism of the beta(2)-adrenergic receptor on response to regular use of albuterol in asthma. Int Arch Allergy Immunol 200I, 124:183-186.

I 12. Kim SH, Oh SY, Oh HB, Kim YK, Cho SH, Kim YY, Min KU: Association of beta2-adrenoreceptor polymorphisms with nocturnal cough among atopic subjects but not with atopy and nonspecific bronchial hyperresponsiveness. J Allergy Clin Immunol 2002, I 09:630-635.

I 13. Holloway JW, Dunbar PR, Riley GA, Sawyer GM, Fitzharris PF, Pearce N, Le Gros GS, Beasley R: Association of beta2-adrenergic receptor polymorphisms with severe asthma. Clin Exp Allergy 2000, 30:1097-II03.

II4. Binaei S, Christensen M, Murphy C, Zhang Q, Quasney M: Beta2adrenergic receptor polymorphisms in children with status asthmaticus. Chest 2003, I 23:375S.

I 15. Hall IP, Wheatley A, Wilding P, Liggett SB: Association of Glu 27 beta 2-adrenoceptor polymorphism with lower airway reactivity in asthmatic subjects. Lancet $1995,345:|2| 3-1214$.

I 16. D'Amato M, Vitiani LR, Petrelli G, Ferrigno L, di Pietro A, Trezza R, Matricardi PM: Association of persistent bronchial hyperresponsiveness with beta2-adrenoceptor (ADRB2) haplotypes. A population study. Am J Respir Crit Care Med 1998, I 58:1968-1973.

I I7. Ulbrecht M, Hergeth MT, Wjst M, Heinrich J, Bickeboller H, Wichmann HE, Weiss EH: Association of beta(2)-adrenoreceptor variants with bronchial hyperresponsiveness. Am J Respir Crit Care Med 2000, 161:469-474.

I 18. Walley AJ, Chavanas S, Moffatt MF, Esnouf RM, Ubhi B, Lawrence R, Wong K, Abecasis GR, Jones EY, Harper JI et al.: Gene polymorphism in Netherton and common atopic disease. Nat Genet 200I, 29: I75-I78.

I19. Sanak M, Pierzchalska M, Bazan-Socha S, Szczeklik A: Enhanced expression of the leukotriene $C(4)$ synthase due to overactive transcription of an allelic variant associated with aspirinintolerant asthma. Am J Respir Cell Mol Biol 2000, 23:290-296.

120. Van Sambeek R, Stevenson DD, Baldasaro M, Lam BK, Zhao J, Yoshida S, Yandora C, Drazen JM, Penrose JF: 5' flanking region polymorphism of the gene encoding leukotriene $C 4$ synthase does not correlate with the aspirin-intolerant asthma phenotype in the United States. J Allergy Clin Immunol 2000, 106:72-76.

121. Kawagishi Y, Mita H, Taniguchi M, Maruyama M, Oosaki R, Higashi N, Kashii T, Kobayashi M, Akiyama K: Leukotriene C4 synthase promoter polymorphism in Japanese patients with aspirininduced asthma. J Allergy Clin Immunol 2002, I 09:936-942.

122. Sayers I, Barton S, Rorke S, Beghe B, Hayward B, Van Eerdewegh P, Keith T, Clough JB, Ye S, Holloway JW et al.: Allelic association and functional studies of promoter polymorphism in the leukotriene C4 synthase gene (LTC4S) in asthma. Thorax 2003, 58:417-424.

123. Huang SK, Zwollo P, Marsh DG: Class II major histocompatibility complex restriction of human $\mathrm{T}$ cell responses to short ragweed allergen, Amb a V. Eur J Immunol 199|, 2 I : |469-|473.

124. Marsh DG, Hsu SH, Roebber M, Ehrlich-Kautzky E, Freidhoff LR, Meyers DA, Pollard MK, Bias WB: HLA-Dw2: a genetic marker for human immune response to short ragweed pollen allergen Ra5. I. Response resulting primarily from natural antigenic exposure. J Exp Med 1982, I55:|439-|45I.

125. Marsh DG, Freidhoff LR, Ehrlich-Kautzky E, Bias WB, Roebber M: Immune responsiveness to Ambrosia artemisiifolia (short 
ragweed) pollen allergen Amb a VI (Ra6) is associated with HLA-DR5 in allergic humans. Immunogenetics 1987, 26:230-236.

126. Freidhoff LR, Ehrlich-Kautzky E, Meyers DA, Ansari AA, Bias WB, Marsh DG: Association of HLA-DR3 with human immune response to Lol $p$ I and Lol p II allergens in allergic subjects. Tissue Antigens 1988, 31:21 I-219.

127. Ansari AA, Freidhoff LR, Meyers DA, Bias WB, Marsh DG: Human immune responsiveness to Lolium perenne pollen allergen Lol p III (rye III) is associated with HLA-DR3 and DR5. Hum Immunol 1989, 25:59-71.

128. Fischer GF, Pickl WF, Fae I, Ebner C, Ferreira F, Breiteneder H, Vikoukal E, Scheiner O, Kraft D: Association between IgE response against Bet $v \mathrm{I}$, the major allergen of birch pollen, and HLADRB alleles. Hum Immunol 1992, 33:259-265.

129. Cardaba B, Vilches C, Martin E, de Andres B, del Pozo V, Hernandez D, Gallardo S, Fernandez JC, Villalba M, Rodriguez R et al.: DR7 and DQ2 are positively associated with immunoglobulin-E response to the main antigen of olive pollen (Ole e I) in allergic patients. Hum Immunol 1993, 38:293-299.

130. Young RP, Dekker JW, Wordsworth BP, Schou C, Pile KD, Matthiesen F, Rosenberg WM, Bell JI, Hopkin JM, Cookson WO: HLADR and HLA-DP genotypes and immunoglobulin E responses to common major allergens. Clin Exp Allergy 1994, 24:43I-439.

13I. Holloway JW, Doull I, Begishvili B, Beasley R, Holgate ST, Howell WM: Lack of evidence of a significant association between HLA-DR, DQ and DP genotypes and atopy in families with HDM allergy. Clin Exp Allergy 1996, 26: I I42-1 I 49.

132. D'Amato M, Scotto d'Abusco A, Maggi E, Menna T, Sacerdoti G, Maurizio SM, lozzino S, De Santo C, Oreste U, Tosi R et al.: Association of responsiveness to the major pollen allergen of Parietaria officinalis with HLA-DRB I* alleles: a multicenter study. Hum Immunol 1996, 46: 100-106.

133. Aron Y, Desmazes-Dufeu N, Matran R, Polla BS, Dusser D, Lockhart A, Swierczewski E: Evidence of a strong, positive association between atopy and the HLA class II alleles DR4 and DR7. Clin Exp Allergy 1996, 26:82I-828.

134. Soriano JB, Ercilla G, Sunyer J, Real FX, Lazaro C, Rodrigo MJ, Estivill $X$, Roca J, Rodriguez-Roisin R, Morell $F$ et al.: HLA class II genes in soybean epidemic asthma patients. Am J Respir Crit Care Med 1997, 1 56:1394-1398.

135. Rihs HP, Barbalho-Krolls T, Huber H, Baur X: No evidence for the influence of HLA class II in alleles in isocyanate-induced asthma. Am J Ind Med 1997, 32:522-527.

136. Dekker JW, Nizankowska E, Schmitz-Schumann M, Pile K, Bochenek G, Dyczek A, Cookson WO, Szczeklik A: Aspirin-induced asthma and HLA-DRBI and HLA-DPBI genotypes. Clin Exp Allergy 1997, 27:574-577.

137. Howell WM, Standring P, Warner JA, Warner JO: HLA class II genotype, HLA-DR B cell surface expression and allergen specific IgE production in atopic and non-atopic members of asthmatic family pedigrees. Clin Exp Allergy 1999, 29(Suppl 4):35-38.

138. Stephan V, Kuehr J, Seibt A, Saueressig H, Zingsem S, Dinh TD, Moseler M, Wahn V, Deichmann KA: Genetic linkage of HLA-class II locus to mite-specific IgE immune responsiveness. Clin Exp Allergy 1999, 29: 1049-1054.

139. Donfack J, Tsalenko A, Hoki DM, Parry R, Solway J, Lester LA, Ober C: HLA-DRB I*0 I alleles are associated with sensitization to cockroach allergens. J Allergy Clin Immunol 2000, 105:960-966.

140. Cho SH, Kim YK, Oh HB, Jung JW, Son JW, Lee MH, Jee HS, Kim YY, Min KU: Association of HLA-DRBI(*)07 and DRBI(*)04 to citrus red mite (Panonychus citri) and house dust mite sensitive asthma. Clin Exp Allergy 2000, 30:1568-1575.

14I. Hu C, Hsu PN, Lin RH, Hsieh KH, Chua KY: HLA DPB I*020I allele is negatively associated with immunoglobulin $E$ responsiveness specific for house dust mite allergens in Taiwan. Clin Exp Allergy 2000, 30:538-545.

142. Woszczek G, Kowalski ML, Borowiec M: Association of asthma and total IgE levels with human leucocyte antigen-DR in patients with grass allergy. Eur Respir J 2002, 20:79-85.

143. Moffatt MF, Schou C, Faux JA, Abecasis GR, James A, Musk AW, Cookson WO: Association between quantitative traits underlying asthma and the HLA-DRB I locus in a family-based population sample. Eur J Hum Genet 200I, 9:34I-346.
144. Kalpaklioglu AF, Turan M: Possible association between cockroach allergy and HLA class II antigens. Ann Allergy Asthme Immunol 2002, 89: I55-I58.

145. Kim YK, Oh SY, Oh HB, Lee B], Son JW, Cho SH, Kim YY, Min KU: Positive association between HLA-DRB I*07 and specific IgE responses to purified major allergens of $D$. pteronyssinus (Der p I and Der p 2). Ann Allergy Asthma Immunol 2002, 88: $170-174$

146. Moffatt MF, Faux JA, Lester S, Pare P, McCluskey J, Spargo R, James A, Musk AW, Cookson WO: Atopy, respiratory function and HLA-DR in Aboriginal Australians. Hum Mol Genet 2003, I 2:625-630.

147. Di Somma C, Charron D, Deichmann K, Buono C, Ruffilli A: Atopic asthma and TNF-308 alleles: linkage disequilibrium and association analyses. Hum Immunol 2003, 64:359-365.

148. Lin YC, Lu CC, Su HJ, Shen CY, Lei HY, Guo YL: The association between tumor necrosis factor, HLA-DR alleles, and IgEmediated asthma in Taiwanese adolescents. Allergy 2002, $57: 831-834$

149. Jeal H, Draper A, Jones M, Harris J, Welsh K, Taylor AN, Cullinan P: HLA associations with occupational sensitization to rat lipocalin allergens: A model for other animal allergies? Allergy Clin Immunol 2003, I I I:795-799.

150. Moffatt MF, James A, Ryan G, Musk AW, Cookson WO: Extended tumour necrosis factor/HLA-DR haplotypes and asthma in an Australian population sample. Thorax |999, 54:757-76|.

15I. Lara-Marquez ML, Yunis JJ, Layrisse Z, Ortega F, Carvallo-Gil E, Montagnani S, Makhatadze N], Pocino M, Granja C, Yunis E: Immunogenetics of atopic asthma: association of DRBI*IIOI DQA I*050 I DQB I*030 I haplotype with Dermatophagoides spp.-sensitive asthma in a sample of the Venezuelan population. Clin Exp Allergy 1999, 29:60-7I.

152. Wilson AG, Symons JA, McDowell TL, McDevitt HO, Duff GW: Effects of a polymorphism in the human tumor necrosis factor alpha promoter on transcriptional activation. Proc Natl Acad Sci U S A 1997, 94:3195-3199.

153. Moffatt MF, Cookson WO: Tumour necrosis factor haplotypes and asthma. Hum Mol Genet 1997, 6:55I-554.

154. Albuquerque RV, Hayden CM, Palmer LJ, Laing IA, Rye PJ, Gibson NA, Burton PR, Goldblatt J, Lesouef PN: Association of polymorphisms within the tumour necrosis factor (TNF) genes and childhood asthma. Clin Exp Allergy 1998, 28:578-584.

155. Trabetti E, Patuzzo C, Malerba G, Galavotti R, Martinati LC, Boner AL, Pignatti PF: Association of a lymphotoxin alpha gene polymorphism and atopy in Italian families. I Med Genet 1999, 36:323-325

156. Chagani T, Pare PD, Zhu S, Weir TD, Bai TR, Behbehani NA, Fitzgerald JM, Sandford AJ: Prevalence of tumor necrosis factor-alpha and angiotensin converting enzyme polymorphisms in mild/ moderate and fatal/near-fatal asthma. Am J Respir Crit Care Med 1999, 160:278-282.

157. Li Kam Wa TC, Mansur AH, Britton J, Williams G, Pavord I, Richards K, Campbell DA, Morton N, Holgate ST, Morrison JF: Association between - 308 tumour necrosis factor promoter polymorphism and bronchial hyperreactivity in asthma. Clin Exp Allergy 1999, 29:1204-1208.

158. Tan EC, Lee BW, Tay AW, Chew FT, Tay AH: Asthma and TNF variants in Chinese and Malays. Allergy 1999, 54:402-403.

159. Malerba G, Trabetti E, Patuzzo C, Lauciello MC, Galavotti R, Pescollderungg L, Boner AL, Pignatti PF: Candidate genes and a genome-wide search in Italian families with atopic asthmatic children. Clin Exp Allergy 1999, 29(Suppl 4):27-30.

160. Castro J, Telleria JJ, Linares P, Blanco-Quiros A: Increased TNFA*2, but not TNFB*I, allele frequency in Spanish atopic patients. J Investig Allergol Clin Immunol 2000, I0: I49-154.

161. Louis R, Leyder E, Malaise M, Bartsch P, Louis E: Lack of association between adult asthma and the tumour necrosis factor alpha308 polymorphism gene. Eur Respir J 2000, 16:604-608.

162. Winchester EC, Millwood IY, Rand L, Penny MA, Kessling AM: Association of the TNF-alpha-308 (G-->A) polymorphism with self-reported history of childhood asthma. Hum Genet 2000, 107:591-596.

163. Witte JS, Palmer LJ, O'Connor RD, Hopkins PJ, Hall JM: Relation between tumour necrosis factor polymorphism TNFalpha308 and risk of asthma. Eur J Hum Genet 2002, 10:82-85. 
164. Buckova D, Holla LI, Vasku A, Znojil V, Vacha J: Lack of association between atopic asthma and the tumor necrosis factor alpha308 gene polymorphism in a Czech population. J Investig Allergol Clin Immunol 2002, I 2:192-197.

165. El Bahlawan L, Christensen M, Binaei S, Murphy C, Zhang Q, Quasney $M$ : Lack of association between the tumor necrosis factoralpha regulatory region genetic polymorphisms associated with elevated tumor necrosis factor-alpha levels and children with asthma. Chest 2003, I 23:374S-375S

166. Noguchi E, Yokouchi Y, Shibasaki M, Inudou M, Nakahara S, Nogami T, Kamioka M, Yamakawa-Kobayashi K, Ichikawa K, Matsui A et al.: Association between TNFA polymorphism and the development of asthma in the Japanese population. Am J Respir Crit Care Med 2002, 166:43-46.

167. Izakovicova Holla L, Vasku A, Izakovic V, Znojil V: The interaction of the polymorphisms in transporter of antigen peptides (TAP) and lymphotoxin alpha (LT-alpha) genes and atopic diseases in the Czech population. Clin Exp Allergy 200I, 31:1418-1423.

168. Ismail A, Bousaffara R, Kaziz J, Zili J, el Kamel A, Tahar Sfar M, Remadi $\mathrm{S}$, Chouchane L: Polymorphism in transporter antigen peptides gene (TAPI) associated with atopy in Tunisians. J Allergy Clin Immunol 1997, 99:2 16-223.

169. Hang LW, Hsia TC, Chen WC, Chen HY, Tsai FJ: TAPI gene Accl polymorphism is associated with atopic bronchial asthma. Clin Lab Anal 2003, 1 7:57-60.

170. Stafforini DM, Numao T, Tsodikov A, Vaitkus D, Fukuda T, Watanabe N, Fueki N, Mclntyre TM, Zimmerman GA, Makino S et al.: Deficiency of platelet-activating factor acetylhydrolase is a severity factor for asthma. J Clin Invest 1999, I 03:989-997.

17I. Satoh N, Asano K, Naoki K, Fukunaga K, Iwata M, Kanazawa M, Yamaguchi K: Plasma platelet-activating factor acetylhydrolase deficiency in Japanese patients with asthma. Am J Respir Crit Care Med 1999, I 59:974-979.

172. Ito S, Noguchi E, Shibasaki M, Yamakawa-Kobayashi K, Watanabe H, Arinami T: Evidence for an association between plasma platelet-activating factor acetylhydrolase deficiency and increased risk of childhood atopic asthma. J Hum Genet 2002, 47:99-101.

173. Kruse S, Mao XQ, Heinzmann A, Blattmann S, Roberts MH, Braun S, Gao PS, Forster J, Kuehr J, Hopkin JM et al.: The lle I98Thr and Ala379Val variants of plasmatic PAF-acetylhydrolase impair catalytical activities and are associated with atopy and asthma. Am J Hum Genet 2000, 66: I522-I530.

174. Gao PS, Mao XQ, Jouanguy E, Pallier A, Doffinger R, Tanaka $Y$, Nakashima H, Otsuka T, Roberts MH, Enomoto T et al.: Nonpathogenic common variants of IFNGRI and IFNGR2 in association with total serum IgE levels. Biochem Biophys Res Commun 1999, 263:425-429.

175. Shin HD, Kim LH, Park BL, Jung JH, Kim JY, Chung IY, Kim JS, Lee JH, Chung $\mathrm{SH}, \mathrm{Kim} \mathrm{YH}$ et al:: Association of Eotaxin gene family with asthma and serum total IgE. Hum Mol Genet 2003, 1 2:1279-1285.

176. Schroeder SA, Gaughan DM, Swift M: Protection against bronchial asthma by CFTR delta F508 mutation: a heterozygote advantage in cystic fibrosis. Nat Med 1995, I:703-705.

177. Mennie M, Gilfillan A, Brock DJ, Liston WA: Heterozygotes for the delta F508 cystic fibrosis allele are not protected against bronchial asthma. Nat Med I 995, I:978-979.

178. Dahl M, Tybjaerg-Hansen A, Lange P, Nordestgaard BG: DeltaF508 heterozygosity in cystic fibrosis and susceptibility to asthma. Lancet 1998, $351: 1911-1913$.

179. Castellani C, Quinzii C, Altieri S, Mastella G, Assael BM: A pilot survey of cystic fibrosis clinical manifestations in CFTR mutation heterozygotes. Genet Test 200I, 5:249-254.

180. de Cid R, Chomel JC, Lazaro C, Sunyer J, Baudis M, Casals T, Le Moual $\mathrm{N}$, Kitzis A, Feingold J, Anto J et al.: CFTR and asthma in the French EGEA study. Eur J Hum Genet 200I, 9:67-69.

181. Lazaro C, de Cid R, Sunyer J, Soriano J, Gimenez J, Alvarez M, Casals $T$, Anto JM, Estivill $X$ : Missense mutations in the cystic fibrosis gene in adult patients with asthma. Hum Mutat 1999, 14:510-519.

182. Tzetis M, Efthymiadou A, Strofalis S, Psychou P, Dimakou A, Pouliou $E$, Doudounakis $S$, Kanavakis E: CFTR gene mutations - including three novel nucleotide substitutions - and haplotype background in patients with asthma, disseminated bronchiectasis and chronic obstructive pulmonary disease. Hum Genet 200I, 108:2|6-22|.

183. Lee YC, Cheon KT, Lee HB, Kim W, Rhee YK, Kim DS: Gene polymorphisms of endothelial nitric oxide synthase and angiotensin-converting enzyme in patients with asthma. Allergy 2000, 55:959-963.

184. Holla LI, Buckova D, Kuhrova V, Stejskalova A, Francova H, Znojil V, Vacha J: Prevalence of endothelial nitric oxide synthase gene polymorphisms in patients with atopic asthma. Clin Exp Allergy 2002, 32:1193-1198.

185. Gao PS, Kawada H, Kasamatsu T, Mao XQ, Roberts MH, Miyamoto Y, Yoshimura M, Saitoh Y, Yasue H, Nakao K et al.: Variants of NOSI, NOS2, and NOS3 genes in asthmatics. Biochem Biophys Res Commun 2000, 267:761-763.

186. Zielinska E, Niewiarowski W, Bodalski J, Stanczyk A, Bolanowski W, Rebowski G: Arylamine $\mathbf{N}$-acetyltransferase (NAT2) gene mutations in children with allergic diseases. Clin Pharmacol Ther 1997, 62:635-642.

187. Gawronska-Szklarz B, Luszawska-Kutrzeba T, Czaja-Bulsa G, Kurzawski G: Relationship between acetylation polymorphism and risk of atopic diseases. Clin Pharmacol Ther 1999, 65:562-569.

188. Nacak M, Aynacioglu AS, Filiz A, Cascorbi I, Erdal ME, Yilmaz N, Ekinci $\mathrm{E}$, Roots I: Association between the $\mathbf{N}$-acetylation genetic polymorphism and bronchial asthma. Br J Clin Pharmacol 2002, 54:67|-674.

189. Makarova SI, Vavilin VA, Lyakhovich VV, Gavalov SM: Allele NAT $2 * 5$ determines resistance to bronchial asthma in children. Bull Exp Biol Med 2000, I 29:575-577.

190. Takeoka S, Unoki M, Onouchi Y, Doi S, Fujiwara H, Miyatake A, Fujita $\mathrm{K}$, Inoue I, Nakamura $\mathrm{Y}$, Tamari M: Amino-acid substitutions in the IKAP gene product significantly increase risk for bronchial asthma in children. J Hum Genet 200I, 46:57-63.

19I. In KH, Asano K, Beier D, Grobholz J, Finn PW, Silverman EK, Silverman ES, Collins T, Fischer AR, Keith TP et al: Naturally occurring mutations in the human 5-lipoxygenase gene promoter that modify transcription factor binding and reporter gene transcription. J Clin Invest 1997, 99: I | 30- I | 37.

192. Drazen JM, Yandava CN, Dube L, Szczerback N, Hippensteel R, Pillari A, Israel E, Schork N, Silverman ES, Katz DA et al.: Pharmacogenetic association between ALOX5 promoter genotype and the response to anti-asthma treatment. Nat Genet 1999 , 22:168-170.

193. Fowler SJ, Hall IP, Wilson AM, Wheatley AP, Lipworth BJ: 5-Lipoxygenase polymorphism and in-vivo response to leukotriene receptor antagonists. Eur / Clin Pharmacol 2002, 58:187-190.

194. Laing IA, Goldblatt J, Eber E, Hayden CM, Rye PJ, Gibson NA, Palmer LJ, Burton PR, Le Souef PN: A polymorphism of the CCI6 gene is associated with an increased risk of asthma. I Med Genet 1998, 35:463-467

195. Laing IA, Hermans C, Bernard A, Burton PR, Goldblatt J, Le Souef PN: Association between plasma CCI6 levels, the A38G polymorphism, and asthma. Am J Respir Crit Care Med 2000, 161:124-127.

196. Gao PS, Mao XQ, Kawai M, Enomoto T, Sasaki S, Tanabe O, Yoshimura K, Shaldon SR, Dake Y, Kitano H et al.: Negative association between asthma and variants of $\mathrm{CCI}(\mathrm{CCIO})$ on chromosome I I q I 3 in British and Japanese populations. Hum Genet 1998, 103:57-59.

197. Choi M, Zhang Z, Ten Kate LP, Collee JM, Gerritsen J, Mukherjee AB: Human uteroglobin gene polymorphisms and genetic susceptibility to asthma. Ann N Y Acad Sci 2000, 923:303-306.

198. Mansur AH, Fryer AA, Hepple M, Strange RC, Spiteri MA: An association study between the Clara cell secretory protein $\mathrm{CC} I 6$ A38G polymorphism and asthma phenotypes. Clin Exp Allergy 2002, 32:994-999.

199. Sengler C, Heinzmann A, Jerkic SP, Haider A, Sommerfeld C, Niggemann B, Lau S, Forster J, Schuster A, Kamin W et al.: Clara cell protein 16 (CCI6) gene polymorphism influences the degree of airway responsiveness in asthmatic children. I Allergy Clin Immunol 2003, III:515-519.

200. Mao XQ, Shirakawa T, Kawai M, Enomoto T, Sasaki S, Dake Y, Kitano $\mathrm{H}$, Hagihara A, Hopkin JM, Morimoto K: Association between asthma and an intragenic variant of CCI 6 on chromosome I I q I 3. Clin Genet 1998, 53:54-56.

20I. Donnadieu E, Cookson WO, Jouvin MH, Kinet JP: Allergy-associated polymorphisms of the Fc epsilon RI beta subunit do not 
impact its two amplification functions. J Immunol 2000, 165:3917-3922.

202. Furumoto Y, Hiraoka S, Kawamoto K, Masaki S, Kitamura T, Okumura K, Ra C: Polymorphisms in FcepsilonRI beta chain do not affect IgE-mediated mast cell activation. Biochem Biophys Res Commun 2000, 273:765-77I.

203. Shirakawa T, Li A, Dubowitz M, Dekker JW, Shaw AE, Faux JA, Ra C, Cookson WO, Hopkin JM: Association between atopy and variants of the beta subunit of the high-affinity immunoglobulin E receptor. Nat Genet 1994, 7:125-129.

204. Li A, Hopkin JM: Atopy phenotype in subjects with variants of the beta subunit of the high affinity IgE receptor. Thorax 1997 , 52:654-655.

205. Green SL, Gaillard MC, Song E, Dewar JB, Halkas A: Polymorphisms of the beta chain of the high-affinity immunoglobulin E receptor (Fcepsilon RI-beta) in South African black and white asthmatic and nonasthmatic individuals. Am J Respir Crit Care Med 1998, 158: |487-1492.

206. Laprise C, Boulet LP, Morissette J, Winstall E, Raymond V: Evidence for association and linkage between atopy, airway hyperresponsiveness, and the beta subunit Glu237Gly variant of the high-affinity receptor for immunoglobulin $E$ in the French-Canadian population. Immunogenetics 2000, 51:695-702.

207. Hill MR, James AL, Faux JA, Ryan G, Hopkin JM, le Souef P, Musk AW, Cookson WO: Fc epsilon RI-beta polymorphism and risk of atopy in a general population sample. Bmj 1995, 3 I I:776-779.

208. Hijazi Z, Haider MZ, Khan MR, Al-Dowaisan AA: High frequency of IgE receptor Fc epsilonRIbeta variant (Leu I 8I/Leu 183) in Kuwaiti Arabs and its association with asthma. Clin Genet 1998, 53:149-152.

209. Hill MR, Cookson WO: A new variant of the beta subunit of the high-affinity receptor for immunoglobulin E (Fc epsilon RIbeta E237G): associations with measures of atopy and bronchial hyper-responsiveness. Hum Mol Genet 1996, 5:959-962.

210. Shirakawa T, Mao XQ, Sasaki S, Enomoto T, Kawai M, Morimoto K, Hopkin J: Association between atopic asthma and a coding variant of Fc epsilon RI beta in a Japanese population. Hum Mol Genet 1996, 5: I I29-I I 30.

211. Rohrbach M, Kraemer R, Liechti-Gallati S: Screening of the Fc epsilon RI-beta-gene in a Swiss population of asthmatic children: no association with E237G and identification of new sequence variations. Dis Markers 1998, 14:177-186.

212. Ishizawa M, Shibasaki M, Yokouchi Y, Noguchi E, Arinami T, Yamakawa-Kobayashi K, Matsui A, Hamaguchi H: No association between atopic asthma and a coding variant of Fc epsilon $R \mathbf{I}$ beta in a Japanese population. J Hum Genet 1999, 44:308-3II.

213. Nagata $H$, Mutoh $H$, Kumahara K, Arimoto $Y$, Tomemori T, Sakurai D, Arase K, Ohno K, Yamakoshi T, Nakano K et al.: Association between nasal allergy and a coding variant of the Fc epsilon RI beta gene Glu237Gly in a Japanese population. Hum Genet 200I, 109:262-266.

214. Palmer LJ, Rye PJ, Gibson NA, Moffatt MF, Goldblatt J, Burton PR, Cookson WO, Lesouef PN: Association of FcepsilonRI-beta polymorphisms with asthma and associated traits in Australian asthmatic families. Clin Exp Allergy 1999, 29: I555-I562.

215. Cox HE, Moffatt MF, Faux JA, Walley AJ, Coleman R, Trembath RC, Cookson WO, Harper Jl: Association of atopic dermatitis to the beta subunit of the high affinity immunoglobulin $E$ receptor. Br J Dermatol 1998, I38:182-187.

216. Castro J, Telleria JJ, Blanco-Quiros A, Linares P, Andion R: Lack of association between atopy and Rsal polymorphism within intron 2 of the $\mathrm{Fc}$ (epsilon)RI-beta gene in a Spanish population sample. Allergy 1998, 53:1083-1086.

217. van Hage-Hamsten M, Johansson E, Kronqvist M, Loughry A, Cookson WO, Moffatt MF: Associations of Fc epsilon RI-beta polymorphisms with immunoglobin $E$ antibody responses to common inhalant allergens in a rural population. Clin Exp Allergy 2002, 32:838-842.

218. Hizawa N, Yamaguchi E, Jinushi E, Kawakami Y: A common FCERIB gene promoter polymorphism influences total serum IgE levels in a Japanese population. Am J Respir Crit Care Med 2000, 161:906-909.

219. Watson MA, Stewart RK, Smith GB, Massey TE, Bell DA: Human glutathione $S$-transferase $P$ I polymorphisms: relationship to lung tissue enzyme activity and population frequency distribution. Carcinogenesis 1998, 19:275-280.
220. Fryer AA, Bianco A, Hepple M, Jones PW, Strange RC, Spiteri MA: Polymorphism at the glutathione S-transferase GSTPI locus. A new marker for bronchial hyperresponsiveness and asthma. Am J Respir Crit Care Med 2000, 161:1437-1442.

22 I. Mapp CE, Fryer AA, De Marzo N, Pozzato V, Padoan M, Boschetto P, Strange RC, Hemmingsen A, Spiteri MA: Glutathione S-transferase GSTPI is a susceptibility gene for occupational asthma induced by isocyanates. J Allergy Clin Immunol 2002, 109:867-872

222. Gilliland FD, Gauderman WJ, Vora H, Rappaport E, Dubeau L: Effects of glutathione-S-transferase $\mathrm{MI}$, $\mathrm{TI}$, and $\mathrm{PI}$ on childhood lung function growth. Am J Respir Crit Care Med 2002, 166:710-716.

223. Kruse S, Kuehr J, Moseler M, Kopp MV, Kurz T, Deichmann KA, Foster PS, Mattes ]: Polymorphisms in the IL 18 gene are associated with specific sensitization to common allergens and allergic rhinitis. J Allergy Clin Immunol 2003, I I I: I I7-I 22.

224. Noguchi E, Shibasaki M, Inudou M, Kamioka M, Yokouchi Y, Yamakawa-Kobayashi K, Hamaguchi H, Matsui A, Arinami T: Association between a new polymorphism in the activationinduced cytidine deaminase gene and atopic asthma and the regulation of total serum IgE levels. J Allergy Clin Immunol 200I, I 08:382-386.

225. Gao PS, Mao XQ, Roberts MH, Arinobu Y, Akaiwa M, Enomoto T, Dake Y, Kawai M, Sasaki S, Hamasaki N et al.: Variants of STAT6 (signal transducer and activator of transcription 6) in atopic asthma. J Med Genet 2000, 37:380-382.

226. Amoli MM, Hand S, Hajeer AH, Jones KP, Rolf S, Sting C, Davies BH, Ollier WE: Polymorphism in the STAT6 gene encodes risk for nut allergy. Genes Immun 2002, 3:220-224.

227. Tamura K, Arakawa H, Suzuki M, Kobayashi Y, Mochizuki H, Kato M, Tokuyama K, Morikawa A: Novel dinucleotide repeat polymorphism in the first exon of the STAT-6 gene is associated with allergic diseases. Clin Exp Allergy 200I, 3 I:I509-15I4.

228. Duetsch G, Illig T, Loesgen S, Rohde K, Klopp N, Herbon N, Gohlke $\mathrm{H}$, Altmueller J, Wjst M: STAT6 as an asthma candidate gene: polymorphism-screening, association and haplotype analysis in a Caucasian sib-pair study. Hum Mol Genet 2002, II:613-62I.

229. Nagarkatti R, Rao CB, Rishi JP, Chetiwal R, Shandilya V, Vijayan V, Kumar R, Pemde HK, Sharma SK, Sharma S et al.: Association of IFNG gene polymorphism with asthma in the Indian population. J Allergy Clin Immunol 2002, I I 0:4 I 0-4 I 2

230. Grasemann H, Yandava CN, Storm van's Gravesande K, Deykin A, Pillari A, Ma J, Sonna LA, Lilly C, Stampfer MJ, Israel E et al.: A neuronal NO synthase (NOSI) gene polymorphism is associated with asthma. Biochem Biophys Res Commun 2000, 272:391-394.

23I. Moffatt MF, Schou C, Faux JA, Cookson WO: Germline TCR-A restriction of immunoglobulin $\mathrm{E}$ responses to allergen. Immunogenetics 1997, 46:226-230.

232. Malerba G, Patuzzo C, Trabetti E, Lauciello MC, Galavotti R, Pescollderungg L, Whalen MB, Zanoni G, Martinati LC, Boner AL et al:: Chromosome 14 linkage analysis and mutation study of 2 serpin genes in allergic asthmatic families. J Allergy Clin Immunol 2001, 107:654-658.

233. Mitsuyasu $H$, Yanagihara $Y$, Mao $X Q$, Gao PS, Arinobu $Y$, Ihara $K$, Takabayashi A, Hara T, Enomoto T, Sasaki $S$ et al.: Cutting edge: dominant effect of Ile50Val variant of the human IL-4 receptor alpha-chain in IgE synthesis. I Immunol I999, I62:1227-| 231.

234. Mitsuyasu $\mathrm{H}$, Izuhara $\mathrm{K}$, Mao XQ, Gao PS, Arinobu Y, Enomoto T, Kawai M, Sasaki S, Dake Y, Hamasaki N et al.: lle50Val variant of IL4R alpha upregulates IgE synthesis and associates with atopic asthma. Nat Genet 1998, 19: I 19-120.

235. Noguchi E, Shibasaki M, Arinami T, Takeda K, Yokouchi Y, Kobayashi $\mathrm{K}$, Imoto N, Nakahara S, Matsui A, Hamaguchi H: No association between atopy/asthma and the ILe50Val polymorphism of IL-4 receptor. Am J Respir Crit Care Med 1999, 160:342-345.

236. Tan EC, Lee BW, Chew FT, Shek L, Tay AW, Tay AH: IL-4Ralpha gene Ile50Val polymorphism. Allergy 1999, 54:1005-1007.

237. Izuhara K, Yanagihara Y, Hamasaki N, Shirakawa T, Hopkin JM: Atopy and the human IL-4 receptor alpha chain. J Allergy Clin Immunol 2000, 106:S65-7I.

238. Oiso N, Fukai K, Ishii M: Interleukin 4 receptor alpha chain polymorphism Gln55IArg is associated with adult atopic dermatitis in Japan. Br J Dermatol 2000, I 42:1003-1006.

239. Haagerup A, Bjerke T, Schiotz PO, Dahl R, Binderup HG, Kruse TA No linkage and association of atopy to chromosome 16 
including the interleukin-4 receptor gene. Allergy 200I, 56:775-779.

240. Mujica-Lopez KI, Flores-Martinez SE, Ramos-Zepeda R, CastanedaRamos SA, Gazca-Aguilar A, Garcia-Perez J, Sanchez-Corona J: Association analysis of polymorphisms in the interleukin-4 receptor (alpha) gene with atopic asthma in patients from western Mexico. Eur J Immunogenet 2002, 29:375-378.

24I. Kruse S, Japha T, Tedner M, Sparholt SH, Forster J, Kuehr J, Deichmann KA: The polymorphisms S503P and Q576R in the interleukin-4 receptor alpha gene are associated with atopy and influence the signal transduction. Immunology 1999, 96:365-37I.

242. Hershey GK, Friedrich MF, Esswein LA, Thomas ML, Chatila TA: The association of atopy with a gain-of-function mutation in the alpha subunit of the interleukin-4 receptor. $N$ Engl J Med I997, 337:1720-1725.

243. Wang HY, Shelburne CP, Zamorano J, Kelly AE, Ryan JJ, Keegan AD: Cutting edge: effects of an allergy-associated mutation in the human IL-4R alpha (Q576R) on human IL-4-induced signal transduction. J Immunol 1999, 162:4385-4389.

244. Noguchi E, Shibasaki M, Arinami T, Takeda K, Yokouchi Y, Kobayashi $\mathrm{K}$, Imoto N, Nakahara S, Matsui A, Hamaguchi H: Lack of association of atopylasthma and the interleukin-4 receptor alpha gene in Japanese. Clin Exp Allergy 1999, 29:228-233.

245. Rosa-Rosa L, Zimmermann N, Bernstein JA, Rothenberg ME, Khurana Hershey GK: The R576 IL-4 receptor alpha allele correlates with asthma severity. J Allergy Clin Immunol 1999, I04: I008-I0I4.

246. Patuzzo C, Trabetti E, Malerba G, Martinati LC, Boner AL, Pescollderungg $L$, Zanoni G, Pignatti PF: No linkage or association of the IL-4Ralpha gene Q576R mutation with atopic asthma in Italian families. J Med Genet 2000, 37:382-384.

247. Andrews RP, Burrell L, Rosa-Rosa L, Cunningham CM, Brzezinski JL, Bernstein JA, Khurana Hershey GK: Analysis of the Ser786Pro interleukin-4 receptor alpha allelic variant in allergic and nonallergic asthma and its functional consequences. Clin Immunol 200I, 100:298-304.

248. Hackstein H, Hofmann H, Bohnert A, Bein G: Definition of human interleukin-4 receptor alpha chain haplotypes and allelic association with atopy markers. Hum Immunol 1999, 60:1119-1127.

249. Kauppi P, Lindblad-Toh K, Sevon P, Toivonen HT, Rioux JD, Villapakkam A, Laitinen LA, Hudson TJ, Kere J, Laitinen T: A second-generation association study of the $5 \mathrm{q} 3 \mathrm{I}$ cytokine gene cluster and the interleukin-4 receptor in asthma. Genomics 200I, 77:35-42.

250. Risma KA, Wang N, Andrews RP, Cunningham CM, Ericksen MB, Bernstein JA, Chakraborty R, Hershey GK: V75R576 IL-4 receptor alpha is associated with allergic asthma and enhanced IL-4 receptor function. I Immunol 2002, 169:1604-1610.

25I. Bottini N, Borgiani P, Otsu A, Saccucci P, Stefanini L, Greco E, Fontana L, Hopkin JM, Mao XQ, Shirakawa T: IL-4 receptor alpha chain genetic polymorphism and total IgE levels in the English population: two-locus haplotypes are more informative than individual SNPs. Clin Genet 2002, 61:288-292.

252. Kabesch M, Peters W, Carr D, Leupold W, Weiland SK, Von Mutius $\mathrm{E}$ : Association between polymorphisms in caspase recruitment domain containing protein 15 and allergy in two German populations. J Allergy Clin Immunol 2003, I I I:8। 3-8I7.

253. Ogura $Y$, Bonen DK, Inohara N, Nicolae DL, Chen FF, Ramos R, Britton $\mathrm{H}$, Moran T, Karaliuskas R, Duerr RH et al:: A frameshift mutation in NOD2 associated with susceptibility to Crohn's disease. Nature 200 I, 4 I I:603-606.

254. Warpeha KM, Xu W, Liu L, Charles IG, Patterson CC, Ah-Fat F, Harding S, Hart PM, Chakravarthy U, Hughes AE: Genotyping and functional analysis of a polymorphic $(C C T T T)(n)$ repeat of NOS2A in diabetic retinopathy. Faseb J 1999, 13:1825-1832.

255. Konno S, Hizawa N, Yamaguchi E, Jinushi E, Nishimura M: (CCTTT)n repeat polymorphism in the NOS2 gene promoter is associated with atopy. J Allergy Clin Immunol 200I, 108:810-814.

256. Nickel RG, Casolaro V, Wahn U, Beyer K, Barnes KC, Plunkett BS, Freidhoff LR, Sengler C, Plitt JR, Schleimer RP et al.: Atopic dermatitis is associated with a functional mutation in the promoter of the C-C chemokine RANTES. I Immunol 2000, 164:1612-1616.

257. Fryer AA, Spiteri MA, Bianco A, Hepple M, Jones PW, Strange RC, Makki R, Tavernier G, Smilie Fl, Custovic A et al.: The $-\mathbf{4 0 3}$ G.->A promoter polymorphism in the RANTES gene is associated with atopy and asthma. Genes Immun 2000, I:509-5I4.

258. Kozma GT, Falus A, Bojszko A, Krikovszky D, Szabo T, Nagy A, Szalai C: Lack of association between atopic eczema/dermatitis syndrome and polymorphisms in the promoter region of RANTES and regulatory region of MCP-I. Allergy 2002, 57:160-163.

259. Szalai C, Kozma GT, Nagy A, Bojszko A, Krikovszky D, Szabo T, Falus $\mathrm{A}$ : Polymorphism in the gene regulatory region of MCP-I is associated with asthma susceptibility and severity. J Allergy Clin Immunol 200I, 108:375-38I.

260. Hizawa N, Yamaguchi E, Konno S, Tanino Y, Jinushi E, Nishimura M: A functional polymorphism in the RANTES gene promoter is associated with the development of late-onset asthma. Am J Respir Crit Care Med 2002, 166:686-690.

26I. Liu H, Chao D, Nakayama EE, Taguchi H, Goto M, Xin X, Takamatsu JK, Saito H, Ishikawa Y, Akaza T et al.: Polymorphism in RANTES chemokine promoter affects HIV-I disease progression. Proc Natl Acad Sci U S A 1999, 96:458I-4585.

262. Rovin BH, Lu L, Saxena R: A novel polymorphism in the MCP-I gene regulatory region that influences MCP-I expression. Biochem Biophys Res Commun 1999, 259:344-348.

263. Nakamura $H$, Luster $A D$, Nakamura $T$, In KH, Sonna LA, Deykin $A$, Israel E, Drazen JM, Lilly CM: Variant eotaxin: its effects on the asthma phenotype. J Allergy Clin Immunol 200I, 108:946-953.

264. Miyamasu M, Sekiya T, Ohta K, Ra C, Yoshie O, Yamamoto K, Tsuchiya $\mathrm{N}$, Tokunaga $\mathrm{K}$, Hirai $\mathrm{K}$ : Variations in the human CC chemokine eotaxin gene. Genes Immun 200I, 2:46I-463.

265. Tsunemi Y, Saeki H, Nakamura K, Sekiya T, Hirai K, Fujita H, Asano $N$, Tanida $Y$, Kakinuma $T$, Wakugawa $M$ et al.: Eotaxin gene single nucleotide polymorphisms in the promoter and exon regions are not associated with susceptibility to atopic dermatitis, but two of them in the promoter region are associated with serum IgE levels in patients with atopic dermatitis. J Dermatol Sci 2002, 29:222-228.

266. Rigat B, Hubert C, Alhenc-Gelas F, Cambien F, Corvol P, Soubrier F: An insertion/deletion polymorphism in the angiotensin Iconverting enzyme gene accounting for half the variance of serum enzyme levels. I Clin Invest 1990, 86: I 343- I 346.

267. Benessiano J, Crestani B, Mestari F, Klouche W, Neukirch F, HaceinBey S, Durand G, Aubier M: High frequency of a deletion polymorphism of the angiotensin-converting enzyme gene in asthma. J Allergy Clin Immunol 1997, 99:53-57.

268. Holla L, Vasku A, Znojil V, Siskova L, Vacha J: Association of 3 gene polymorphisms with atopic diseases. J Allergy Clin Immunol 1999, 103:702-708.

269. Tomita H, Sato S, Matsuda R, Ogisu N, Mori T, Niimi T, Shimizu S: Genetic polymorphism of the angiotensin-converting enzyme (ACE) in asthmatic patients. Respir Med 1998, 92:1305-1310.

270. Gao PS, Mao XQ, Kawai M, Enomoto T, Sasaki S, Shaldon SR, Dake $Y$, Kitano $H$, Coull $P$, Hagihara $A$ et al.: Lack of association between ACE gene polymorphisms and atopy and asthma in British and Japanese populations. Clin Genet 1998, 54:245-247.

27I. Nakahama $H$, Obata K, Nakajima T, Nakamura $H$, Kitada O, Sugita $M$, Fujita $Y$, Kawada N, Moriyama T: Renin-angiotensin system component gene polymorphism in Japanese bronchial asthma patients. J Asthma 1999, 36: 187-193.

272. Leung TF, Tang NL, Lam CW, Li AM, Chan IH, Ha G: Thromboxane A2 receptor gene polymorphism is associated with the serum concentration of cat-specific immunoglobulin $E$ as well as the development and severity of asthma in Chinese children. Pediatr Allergy Immunol 2002, I3: I0-17.

273. Grainger DJ, Heathcote K, Chiano M, Snieder H, Kemp PR, Metcalfe JC, Carter ND, Spector TD: Genetic control of the circulating concentration of transforming growth factor type betal. Hum Mol Genet 1999, 8:93-97.

274. Pulleyn LJ, Newton R, Adcock IM, Barnes PJ: TGFbeta I allele association with asthma severity. Hum Genet 200I, 109:623-627.

275. Buckova D, Izakovicova Holla L, Benes P, Znojil V, Vacha J: TGFbeta I gene polymorphisms. Allergy 200I, 56:I236-I237.

276. Arkwright PD, Chase JM, Babbage S, Pravica V, David TJ, Hutchinson IV: Atopic dermatitis is associated with a low-producer transforming growth factor beta(I) cytokine genotype. J Allergy Clin Immunol 200I, I08:28I-284. 
277. Ahmed S, Ihara K, Sasaki Y, Nakao F, Nishima S, Fujino T, Hara T: Novel polymorphism in the coding region of the IL- 13 receptor alpha' gene: association study with atopic asthma in the Japanese population. Exp Clin Immunogenet 2000, 17: 18-22.

Publish with Bio Med Central and every scientist can read your work free of charge

"BioMed Central will be the most significant development for disseminating the results of biomedical research in our lifetime. " Sir Paul Nurse, Cancer Research UK

Your research papers will be:

- available free of charge to the entire biomedical community

- peer reviewed and published immediately upon acceptance

- cited in PubMed and archived on PubMed Central

- yours - you keep the copyright

Submit your manuscript here:

http://www.biomedcentral.com/info/publishing_adv.asp
BioMedcentral 